\title{
Does early treatment of macrophage activation syndrome prevent fatal outcome in patients with severe systemic juvenile idiopathic arthritis?
}

\author{
Czy wczesne leczenie zespołu aktywnego makrofaga zapobiegło niepomyślnemu \\ zejściu choroby u pacjenta z ciężką postacią młodzieńczego idiopatycznego \\ zapalenia stawów?
}

\author{
Marzena Janczewska ${ }^{1,2}$, Teresa Kołcun-Penkowska ${ }^{1}$ \\ ${ }^{1}$ Children's Hospital, Olsztyn \\ ${ }^{2}$ Department of Pharmacology and Toxicology, Faculty of Medical Sciences, University of Warmia and Mazury, Olsztyn \\ ${ }^{1}$ Wojewódzki Specjalityczny Szpital Dziecięcy w Olsztynie \\ ${ }^{2}$ Katedra Farmakologii i Toksykologii, Wydział Nauk Medycznych, Uniwersytet Warmińsko-Mazurski w Olsztynie
}

Key words: macrophage, activation, syndrome.

Słowa kluczowe: zespót, aktywnego, makrofaga.

\section{Sum mary}

Macrophage activation syndrome (MAS), a rare complication of various diseases, mainly systemic inflammatory connective tissue disorders, is being increasingly recognized. Most frequently MAS occurs in systemic juvenile idiopathic arthritis (sJIA), yet description of typical clinical features is challenging. Prognosis of the syndrome is often poor therefore prompt diagnosis and appropriate medical treatment are critical for survival.

We report the case of MAS diagnosed in a 7-year-old boy with severe generalized sJIA presenting description of our dilemmas associated with the diagnosis. We identified the condition as MAS on the basis of criteria defined by Ravelli et al. To make diagnosis of MAS was difficult, especially because some clinical symptoms are characteristic both for MAS and sJIA. Owing to deterioration of a general condition of the patient we took the risk of including treatment with cyclosporine. This treatment significantly improved the condition of the child and in our opinion prevented a fatal outcome.

\section{Introduction}

Macrophage activation syndrome (MAS) belongs to a large heterogenic group of diseases. These conditions are characterized by excessive activity and proliferation of $T$ lymphocytes and macrophages. Macrophage activation syndrome occurs in children with rheumatic diseases:

\section{Streszczenie}

Zespół aktywnego makrofaga (macrophage activation syndrome MAS) jest rzadkim, jednak coraz częściej rozpoznawanym powikłaniem różnych chorób, głównie układowych chorób tkanki łącznej. Zespół aktywnego makrofaga najczęściej występuje w przebiegu młodzieńczego idiopatycznego zapalenia stawów (systemic juvenile idiopathic arthritis - sJIA), ale opisanie charakterystycznych objawów wciąż stanowi wyzwanie. Rokowanie w przypadku tego zespołu jest poważne, a szybkie rozpoznanie i odpowiednie leczenie decydują o przeżyciu chorego. W artykule przedstawiono przypadek MAS u 7-letniego chłopca z ciężką uogólnioną postacią sJIA oraz trudności związane z ustaleniem rozpoznania. Zespół aktywnego makrofaga rozpoznano na podstawie obowiązujących wówczas kryteriów Ravellego i wsp. Postawienie diagnozy MAS było trudne, zwłaszcza że niektóre objawy kliniczne są charakterystyczne zarówno dla MAS, jak i dla sJIA. Z powodu pogorszenia się stanu ogólnego dziecka podjęto ryzyko zastosowania cyklosporyny. Leczenie to znacznie poprawito stan chorego i w opinii autorów zapobiegło niepomyślnemu zejściu choroby.

systemic-onset juvenile idiopathic arthritis (sJIA), systemic lupus erythematosus (SLE), dermatomyositis, scleroderma, polyarteritis nodosa (PAN), Kawasaki disease [1].

We report the case of MAS diagnosed in a 7-year-old boy hospitalized in February and March 2010 due to new incidents of severe generalized SIIA. Owing to deterio-

Address for correspondence:

Marzena Janczewska, MD, Children's Hospital, Żolnierska 18 A, 10-561 Olsztyn, e-mail: marzena.janczewska@uwm.edu.pl

Submitted: 6.01 .2014 
ration of general condition of a patient we decided to introduce treatment with cyclosporine, despite the fact that not all MAS criteria were met. In our opinion this treatment prevented a fatal outcome.

\section{Case report}

In February 2010, a boy aged 7 7/12 was admitted to our department because of recurring spiking fever up to $39^{\circ} \mathrm{C}$ lasting 8 days, resistant to ibuprofen, concomitant with lower limb pain (the patient was unable to walk), purpuric rash, swollen face and crus, as well as hand, shoulder, knee and foot joints movement limitation and swelling. Two days prior to admission he had a fit. On account of his delayed psychomotor development (he began to sit and walk at the age of 2 and 3, respectively), discrete left-sided hemiparesis, seizures (over last 2 years no medication administered) and suspected Asperger syndrome, he was regularly reviewed by a neurologist and a psychologist.

The patient was admitted in critical condition, suffering from hyperaesthesia and fatigue. Physical examination revealed skin paleness, significant muscle weakness in the upper and lower limbs (he could not walk or lift up his arms), knee joint effusion as well as attenuation of vesicular sound in left lung. Laboratory tests showed increased erythrocyte sedimentation rate (ESR) $83 \mathrm{~mm} / \mathrm{h}$, C-reactive protein (CRP) $15.6 \mathrm{mg} / \mathrm{dl}$, white blood cells (WBC) $21.3 \times 10^{9} /$, blood platelets (PLT) 493 $\times 10^{9} /$, dysproteinemia with hypoalbuminemia (Albumin 39.2\%), increased lactate dehydrogenase (LDH 709 $\mathrm{U} / \mathrm{I}$ ) and aspartate transaminase (AST $87 \mathrm{U} / \mathrm{l}$ ) as well as positive immunoglobulin (lg) A antibodies against $M y$ coplasma pneumoniae (17.49 VE; positive result > 9). Ultrasound scan revealed fluid in both knee joints and spleen enlargement.

Despite intensive antibiotics therapy (Biofuroksym $3 \times 600 \mathrm{mg}$ i.v., Fromilid $2 \times 250 \mathrm{mg}$ p.o.) and NSAIDs (Naproxen $2 \times 200 \mathrm{mg}$ p.o.) general condition of the patient worsened in the second week after admission (spiking fever, peritoneal effusion, dyspnoea and subcutaneous tissue swelling increased). In spite of switching to Tarcefoksym $4 \times 0.5 \mathrm{~g}$ i.v. and Amikin $2 \times 150 \mathrm{mg}$ i.v., then to Meronem $400 \mathrm{mg}$ TID, introducing Metypred 16 mg daily, Flebogamma IV $2 \times 20$ g and Albumin 20\% $100 \mathrm{ml}$ intravenous administration, the patient's clinical state was still deteriorating. Weight loss, weakness, significant hyperaesthesia, fatigue and central nervous system symptoms (apathy, hand tremor, high-pitched cry) were noted. Lower limb and abdominal pain were rated at 10 according to VAS scale. Additional laboratory tests showed anemia (ESR $3.0 \times 10^{9} / \mathrm{l}, \mathrm{Hb} 8.4 \mathrm{~g} / \mathrm{dl}$, $\mathrm{Ht}$ 24.7\%), decreased serum iron (Fe $15 \mu \mathrm{g} / \mathrm{dl}$ ), elevated

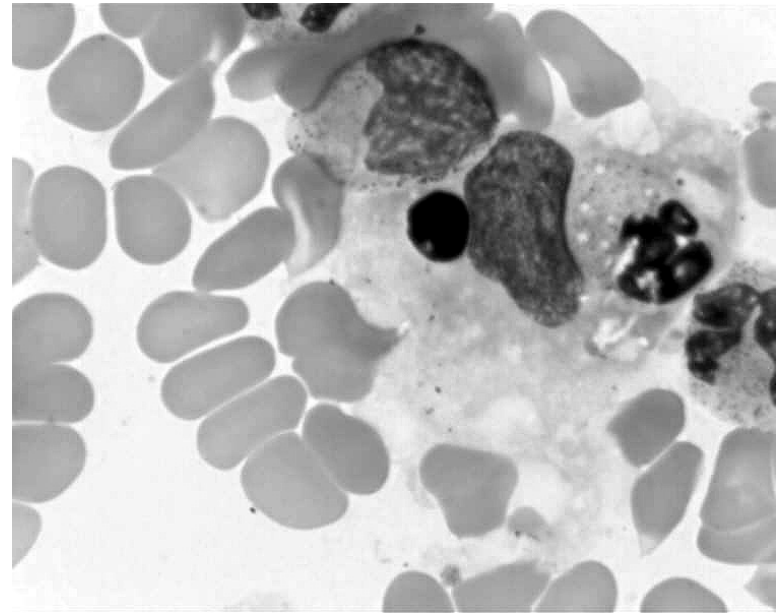

Fig. 1. Bone marrow biopsy revealed the presence of well - differentiated actively phagocytising macrophages

serum fibrynogen $6.04 \mathrm{~g} / \mathrm{l}$, triglycerides $171 \mathrm{mg} / \mathrm{dl}$, D-dimers $6379.8 \mathrm{ng} / \mathrm{ml}$, ferritin > $1000.0 \mathrm{ng} / \mathrm{ml}$, platelets 848 $\times 10^{9} /$, reticulocytes $39 \%$ as well as hyponatremia 127 $\mathrm{mmol} / \mathrm{l}$. Ultrasound scan revealed synovial hyperplasia in both knee joints. Bone marrow biopsy (Fig. 1) revealed the presence of well - differentiated actively phagocytising macrophages. Since patient's general condition was worsening we decided to administer cyclosporine $30 \mathrm{mg}$ BD (up to $40 \mathrm{mg}$ BD on day 9) which led to clinical stabilization and improvement of laboratory tests results. The boy was discharged in clinical remission after 6 weeks of treatment.

Due to a new exacerbations, the patient was admitted to the Institute of Rheumatology in Warsaw. In the $6^{\text {th }}$ week of cyclosporine treatment an increase in drug level and serum creatinine were noted leading to strong suspicion of acute renal failure. Equoral was discontinued and kidney function tests returned to normal. However, in a view of patient's worsening clinical condition, Methotrexat a $2.5 \mathrm{mg} 5$ tabl weekly (MTX) was started. The boy was on IV immunoglobulins for 6 months. Later the patient was sent to a local rheumatology out-patient clinic.

\section{Discussion}

Among rheumatic diseases, MAS occurs most frequently in SJIA [2]. We report a paediatric case of severe SIIA complicated by MAS which due to the risk of death was treated with cyclosporine before all results of laboratory tests were available. Constellation of symptoms like high fever lasting 4 weeks, evanescent rash, knee and ankle arthritis, splenomegaly, serositis, increased ESR, CRP, WBC and PLT, as well as RF $5 \mathrm{lU} / \mathrm{ml}$ and $9 \mathrm{lU} / \mathrm{ml}$ 
Table I. Criteria for MAS acc. to Ravelli et al. [7] and signs, symptoms and laboratory tests results present in the reported case

\begin{tabular}{|c|c|}
\hline Major MAS features 2010 & $\begin{array}{c}\text { Patient signs, symptoms and laboratory } \\
\text { tests results }\end{array}$ \\
\hline \multicolumn{2}{|c|}{ Clinical features } \\
\hline nonremitting high fever & fever of $39^{\circ} \mathrm{C}$ \\
\hline \multicolumn{2}{|l|}{ hepatomegaly } \\
\hline splenomegaly & $\begin{array}{c}\text { splenomegaly } \\
\text { (103 mm assessed sonographically) }\end{array}$ \\
\hline \multicolumn{2}{|l|}{ lymphadenopathy } \\
\hline \multicolumn{2}{|l|}{ hemorrhage } \\
\hline central nervous system dysfunction & seizures, irritability, headache \\
\hline \multicolumn{2}{|c|}{ Laboratory tests } \\
\hline hemoglobin $\leq 9 \mathrm{~g} / \mathrm{dl}$ & hemoglobin $8.4 \mathrm{~g} / \mathrm{dl}$ \\
\hline \multicolumn{2}{|l|}{ leukopenia } \\
\hline \multicolumn{2}{|l|}{ trombocytopenia } \\
\hline $\mathrm{AST} \geq 40 \mathrm{IU} / \mathrm{I}$ & AST $87 \mathrm{IU} / \mathrm{I}$ \\
\hline $\mathrm{ALT} \geq 40 \mathrm{IU} / \mathrm{I}$ & ALT $50 \mathrm{IU} / \mathrm{I}$ \\
\hline $\mathrm{LDH} \geq 900 \mathrm{IU} / \mathrm{I}$ & LDH 709 IU/I \\
\hline \multicolumn{2}{|l|}{ fibrinogen $\leq 2.5 \mathrm{~g} / \mathrm{l}$} \\
\hline triglycerides $\geq 160$ mg/dl & $\begin{array}{l}171 \mathrm{mg} / \mathrm{dl} \\
\text { (normal range in children } \leq 125 \mathrm{mg} / \mathrm{dl} \text { ) }\end{array}$ \\
\hline $\mathrm{Na} \leq 130 \mathrm{mmol} / \mathrm{l}$ & $\mathrm{Na} 127 \mathrm{mmol} / \mathrm{l}$ \\
\hline albumin $\leq 25 \mathrm{~g} / \mathrm{l}$ & albumin $20 \mathrm{~g} / \mathrm{l}$ \\
\hline ferritin $\geq 10000 \mu \mathrm{g} / \mathrm{l}$ & ferritin > 1000.0 ng/ml (ULN 160 ng/ml) \\
\hline fibrin degradation products & D-dimers 6379.8 ng/ml \\
\hline \multicolumn{2}{|c|}{ Histopathology } \\
\hline $\begin{array}{l}\text { bone marrow macrophage } \\
\text { hemophagocytosis }\end{array}$ & $\begin{array}{l}\text { bone marrow macrophage } \\
\text { hemophagocytosis }\end{array}$ \\
\hline
\end{tabular}

made us suspect sJIA. This set of symptoms is wildly described in the literature [3, 4]. Additionally, decreased number of NK cells and reduced NK cell catalytic activity are features that distinguish sJIA from other forms of JIA $[5,6]$. During process of diagnosis we considered an overlap syndrome with dermatomyositis since following symptoms were present: lower limb pain, significant muscle weakness in the upper and lower limbs, hyperaesthesia and fatigue, dyspnoea, lung involvement.
As presented in Table I our patient fulfilled the criteria of MAS acc. to Ravelli et al. that were in use at that time [7]. These preliminary diagnostic guidelines for MAS in SJIA include: high fever, rash, splenomegaly, oliguria, hypertriglyceridemia, hyperferritinemia, anemia, hypoalbuminemia, low serum sodium, elevated serum $\mathrm{LDH}$, abnormal clotting tests, serositis as well as presence of macrophages in bone marrow biopsy [7, 8]. According to newly developed diagnostic criteria for MAS 
Table II. Current criteria for MAS [10] and signs, symptoms and laboratory tests results present in the reported case

\begin{tabular}{|c|c|}
\hline MAS criteria in active sJIA & $\begin{array}{c}\text { Patient signs, symptoms and laboratory } \\
\text { tests results }\end{array}$ \\
\hline \multicolumn{2}{|c|}{ Laboratory tests } \\
\hline \multicolumn{2}{|l|}{ platelets $<262 \times 10^{9} / l$} \\
\hline AST $>59 \mathrm{IU} / \mathrm{I}$ & AST 87 IU/I \\
\hline \multicolumn{2}{|l|}{$W B C<4 \times 10^{9} / 1$} \\
\hline \multicolumn{2}{|l|}{ hypofibrinogenemia $\leq 2.5 \mathrm{~g} / \mathrm{l}$} \\
\hline \multicolumn{2}{|c|}{ Clinical criteria } \\
\hline CNS dysfunction & seizures, irritability, headache \\
\hline hemorrhage & purpura, bruising \\
\hline \multicolumn{2}{|l|}{ hepatomegaly } \\
\hline \multicolumn{2}{|c|}{ Histopathology } \\
\hline $\begin{array}{l}\text { bone marrow macrophage } \\
\text { hemophagocytosis }\end{array}$ & $\begin{array}{l}\text { bone marrow macrophage } \\
\text { hemophagocytosis }\end{array}$ \\
\hline
\end{tabular}

the presence of two or more of laboratory or clinical criteria is required [9-11]. As shown in Table II our patient met 4 out of 8 of these.

Lack of cytopenia in a described patient could have been masked by leucocytosis and thrombocytosis that occur in SIIA. Moreover, cytopenia and hypofibrynogenemia are more characteristic for hemophagocytic lymphohistiocytosis.

Management of MAS involves elimination of triggering factors, usually viral infection, and treatment with high-dose corticosteroids, cyclosporine A, intravenous immunoglobulins and etoposide.

In our opinion, the factor that had presumably triggered the disease was one of the following: M. pneumoniae, Parvovirus B19, Cytomegalovirus or EBV infection.

\section{Conclusions}

Diagnosing MAS is difficult, especially at the early stage. Considering the severe course of MAS, diagnosis should be established as soon as possible. Early introduction of the suitable therapy and cyclosporine A may prevent further complications.

Authors declare no conflict of interest.

\section{References}

1. Gietka P, Wieteska-Klimczak A, Smorczewska-Kiljan A, Rutkowska-Sak L. Reactive hemophagocytic syndromes in children with rheumatic diseases. Reumatologia 2011; 49: 96-107.
2. Wulffraat NM. Defining criteria for macrophage activation syndrome, a process towards early recognition and treatment. J Rheumatol 2011; 38: 593-594.

3. Gurion R, Lehman TJ, Moorthy LN. Systemic arthritis in children: a review of clinical presentation and treatment. Int J Inflam 2012; 2012: 271569.

4. Ravelli A, Grom AA, Behrens EM, Cron RQ. Macrophage activation syndrome as part of systemic juvenile idiopathic arthritis: diagnosis, genetics, pathophysiology and treatment. Genes Immun 2012; 13: 289-298.

5. Ravelli A, Jung L. Macrophage activation syndrome. Medscape Reference 2010; 6:

6. Villanueva J, Lee S, Giannini EH, et al. Natural killer cell dysfunction is a distinguishing feature of systemic onset juvenile rheumatoid arthritis and macrophage activation syndrome. Arthritis Res Ther 2005; 7: R30-37.

7. Ravelli A, Magni-Manzoni S, Pistorio A, et al. Preliminary diagnostic guidelines for macrophage activation syndrome complicating systemic juvenile idiopathic arthritis. J Pediatr 2005; 146: 598-604.

8. Zoń-Giebel A, Giebel S. Zespół aktywacji makrofagów - reaktywna postać limfohistiocytozy hemofagocytarnej. Reumatologia 2008; 46: 21-26.

9. Davì S, Consolaro A, Guseinova D, et al. An international consensus survey of diagnostic criteria for macrophage activation syndrome in systemic juvenile idiopathic arthritis. J Rheumatol 2011; 38: 764-768.

10. Davi S, Lattanzi B, Demirkaya E. Toward the development of new diagnostic criteria for macrophage activation syndrome in systemic juvenile idiopathic arthritis. Ann Paediatr Rheum 2012; 1: 1-7.

11. Ravelli A, Davi S, Parodi A. Macrophage activation syndrome workup. Medscape Reference 2012; 12. Available at: http:// emedicine.medscape.com/article/1380671-workup 